Mеталлофиз. новейшие технол. / Metallofiz. Noveishie Tekhnol. @ 2018 ИМФ (Институт металлофизики 2018, т. 40, № 5, сc. 615-623 / DOI: $10.15407 /$ mfint.40.05.0615 им. Г. В. Курдюмова НАН Украины) Оттиски доступны непосредственно от издателя

Фотокопирование разрешено только

Напечатано в Украине.

в соответствии с лицензией

PACSnumbers: 61.43.Hv, 68.37.Hk, 68.55.J-, 82.45.Qr, 82.45.Hk, 82.45.Yz, 83.60.Np

\title{
Effect of Magnetic Field on Electrodeposition of Nanosize Structures
}

\author{
E. A. Bondar and D. A. Luzhbin*
}

G. V. Kurdyumov Institute for Metal Physics, N.A.S. of Ukraine, 36 Academician Vernadsky Blvd., UA-03142 Kyiv, Ukraine

"National Yang-Ming University,

155 Li-Nong Str.,

112 Taipei, Taiwan

The impact of an external magnetic field on the morphology of nanosize clusters obtained by magnetoelectrolysis of $\mathrm{CuSO}_{4}$ aqueous solution within the applied magnetic field up to $0.31 \mathrm{~T}$ is investigated by the controlled potential method. As found, the morphology of obtained electrodeposits is significantly changed by the applied magnetic field. In a zero magnetic field, one has an isotropic growth of deposited aggregates, whereas for nonzero fields, there appear preferred directions of growth for the field oriented either perpendicular or parallel to the electric current lines. The observed ramified electrodeposits have the fractal structure, with the fractal dimension being dependent on the magnetic field strength and orientation. The features observed can be explained taking into account the magnetohydrodynamic (MHD) convection induced by the Lorentz force, which affects the natural convection due to concentration gradient in electrolyte near the cathode surface both along the plane of the electrode and perpendicular to it. In this way, nanoobjects of various structures (magnetic-field-driven) and different size (electrolysis-timedependent) can be fabricated in a controlled way. Additional feature observed in the present work, viz., change of the sign of the potential difference between the lower and upper probes with increase of the magnetic field, evidences the corresponding change of sign of the concentration gradient along the cathode surface. This feature allows us to explain the impact of magnetic field in the parallel orientation (where no Lorentz forces act) by interplay of

Corresponding author: Evgen Anatoliyovych Bondar

E-mail: evg.bondar@ukr.net

Citation: E. A. Bondar and D. A. Luzhbin, Effect of Magnetic Field on Electrodeposition of Nanosize Structures, Metallofiz. Noveishie Tekhnol., 40, No. 5: 615-623 (2018), DOI: $10.15407 /$ mfint.40.05.0615. 
the MHD effects and the diffusion over the cathode plane.

Key words: fractal structure, magnetic field, Lorentz force, concentration gradient.

Потенціостатичною методою досліджено вплив зовнішнього сталого магнетного поля на морфологію нанорозмірних кластерів, одержаних магнетоелектролізою водного розчину $\mathrm{CuSO}_{4}$ в зовнішньому магнетному полі величиною до 0,31 Т. Встановлено, що морфологія одержаних осадів істотно змінюеться накладеним магнетним полем. В нульовому полі кластери, що осаджуються, не мають виділених напрямків зростання, в той час як в ненульовому магнетному полі з'являється переважні напрямки зростання як при магнетному полі, зорієнтованому перпендикулярно до електричних токових ліній, так і при їх паралельній орієнтації. Розгалужені структури осадів, що спостерігалися, мають фрактальну структуру, фрактальна розмірність якої залежить від величини й орієнтації магнетного поля. Спостережені ефекти можна пояснити магнетогідродинамічною (МГД) конвекцією, яку викликано дією Лорентцової сили, яка впливає на природню конвекцію, що спричинена градієнтом концентрації в електроліті в прикатодному шарі як вздовж, так і поперек поверхні електроди. Таким чином, нанорозмірні об’єкти різноманітної структури (яка визначається магнетним полем) та розміру (який визначається часом електролізи) можуть бути одержані контрольованим чином. Ще одне явище, спостережене в даній роботі, а саме, зміна знаку ріжниці потенціялів між верхнім і нижнім зондами при зростанні магнетного поля, свідчить про супутню зміну знаку градієнту концентрації вздовж поверхні катоди. Це уможливлює пояснити вплив магнетного поля у випадку паралельної орієнтації (де не діють Лорентцові сили) взаємним впливом МГД-ефектів і дифузії вздовж поверхні катоди.

Ключові слова: фрактальна структура, магнетне поле, Лорентцова сила, градієнт концентрації.

Потенциостатическим методом исследовано влияние внешнего постоянного магнитного поля на морфологию наноразмерных кластеров, полученных магнитоэлектролизом водного раствора $\mathrm{CuSO}_{4}$ во внешнем магнитном поле величиной до 0,31 T. Установлено, что морфология полученных осадков существенно изменяется приложенным магнитным полем. В нулевом поле осаждённые кластеры не имеют выделенных направлений роста, в то время как в ненулевом магнитном поле появляется преимущественное направление роста как при магнитном поле, ориентированном перпендикулярно электрическим токовым линиям, так и при их параллельной ориентации. Наблюдаемые разветвлённые структуры осадков имеют фрактальную структуру, фрактальная размеренность которой зависит от величины и ориентации магнитного поля. Наблюдаемые эффекты могут быть объяснены магнитогидродинамической (МГД) конвекцией, вызванной действием силы Лоренца, которая влияет на естественную конвекцию, вызванную градиентом концентрации в электролите в околокатодном пространстве как вдоль, так и поперёк поверхности электрода. Таким образом, наноразмерные объекты различной структуры (определя- 
емой магнитным полем) и размера (определяемого временем электролиза) могут быть получены контролируемым образом. Ещё одно явление, обнаруженное в данной работе, а именно, изменение знака разности потенциалов между верхним и нижним зондами при увеличении магнитного поля, свидетельствует о сопутствующем изменении знака градиента концентрации вдоль поверхности катода. Это позволяет объяснить влияние магнитного поля в случае параллельной ориентации (где не действуют силы Лоренца) взаимным влиянием МГД-эффектов и диффузии вдоль поверхности электрода.

Ключевые слова: фрактальная структура, магнитное поле, сила Лоренца, градиент концентрации.

(Received January 18, 2018)

\section{INTRODUCTION}

The deposition of metals from aqueous solutions of their salts is widely used in various branches of industry such as hydrometallurgy, powder metallurgy, anodic coating, etc. [1, 2], as well as in purely physical researches, such as kinetics of electrode processes and surface chemistry, investigation of adsorption on electrode surfaces, electrocrystallization of non-ferrous metals, etc. [1,3-6]. Imposition of an external magnetic field over an electrolytic bath during the deposition process (often-called magnetoelectrolysis) essentially changes the course of electrolytic reaction that in turn essentially changes the output [7-9]. Some of the main advantages of the magnetic field imposition are (i) the acceleration of the corresponding chemical reaction that allows us to deposit more metallic substance with less power consumption, (ii) the change of the deposit morphology that allow us to produce the powders of different granulometry and shape of the constituent particles, and (iii) ability to produce more subtle deposit structures such as ferromagnetic alloys and multilayers, nanowires and multilayer nanowires, dot arrays or nanocontacts $[9,10]$.

But despite the longstanding researches, a clear theoretical understanding and cogent picture of the effects of a magnetic field on an electrolytic reaction is still lacking [8-10], e.g., one of the problems is why the forces acting in an electrochemical cell, which typically differ by four orders of magnitude, all have the measurable effect $[9,10]$.

The purpose of the present work is to outline briefly the general features of our resent preliminary investigations of the effect of static magnetic field on the structure and morphology of the nanosize copper deposits obtained during the electrolysis process. For our study, we have chosen copper-based deposits, since they are ones of the most investigated systems (but nevertheless producing unexpected results [11]), whose results can be easily reproduced, as well as having in mind 
the growing niche the copper is going to occupy in manufacture of computer chips as well as in micro and nanoelectronic devices [12].

Having found empirical rules, which govern the electrodeposition process and define the deposit structure, it is possible to produce in a controlled way the nanosize metallic clusters of various specified structure, morphology, shape and dimensionality, which can be used, e.g., as experimental samples for studying the various properties of nanoparticles as well as in purely applied fields such as, e.g., light absorber in far infrared band [13, 14] (for deposits of fractal structure [15]), or as catalyst carriers in complex chemical reactions [16]. The further step is the development of a self-consistent mathematical model that takes into account all principal features of magnetoelectrolysis (e.g., MHD effects, field-induced magnetization of the ions, surface properties of the growing deposits, etc.) and correctly reproduces the observed experimental results. Having developed such a model, one obtains a powerful tool for theoretical investigation and modelling of the deposit growth processes. The major aspects of such a model are briefly outlined.

\section{EXPERIMENTAL SETUP}

A cylindrical temperature-controlled electrolytic cuvette made of quartz filled with an aqueous electrolyte containing two $\mathrm{Cu}$ sheets (length and width $10 \mathrm{~mm}$, thickness $0.7 \mathrm{~mm}$ ) as working electrode and counter electrode placed vertically at a mutual distance of $1 \mathrm{~cm}$ parallel to each other was used in the present study. The electrolyte consisted of $150 \mathrm{~g} / \mathrm{l}$ of copper sulphate and $50 \mathrm{~g} / \mathrm{l}$ of sulphuric acid and was prepared from distilled water and analytical grade chemicals. To exclude the impact of the initial surfaces, the electrodes were purified by exposing them to a nitric acid and by subsequent two-minute electroplating in the same electrolyte solution at $-100 \mathrm{mV}$ that gives a smooth copper coating over the entire surface of the electrodes. Two additional probes consisted of insulated copper wire having a diameter of $80 \mu \mathrm{m}$ were placed in the cathode area at the top and the bottom of the cathode on a distance of about 10-20 $\mu \mathrm{m}$ from its surface. The wires' insulating layer was removed from the side opposite to the cathode surface so that the total distance between the cathode and the probes active area was about $100 \mu \mathrm{m}$.

All experiments were performed in the homogeneous field of an electromagnet producing the magnetic field $B$ up to $0.31 \mathrm{~T}$. The field $B$ was oriented either perpendicular or parallel to the electric current lines in the electrochemical cell. The work regime of $12 \mathrm{~V}$ was established during the first 60 seconds with $0.2 \mathrm{~V} / \mathrm{s}$ voltage sweep. The cathode and the probes potentials are referred to $\mathrm{Cl} / \mathrm{Ag}$ reference electrode.

To study the electrolysis process, methods of polarization curves and probe potentiometry were used. Time dependence of the electroly- 
sis current, surface cathode potential as well as potentials of the lower and upper probes were measured at a room temperature. Polarization curves were collected in the potentiodynamic regime by an automatic recorder. The structure of copper deposits obtained during the magnetoelectrolysis was investigated by means of the scanning electron microscope $\mathrm{P} Э \mathrm{M \Gamma}-100$. The corresponding flows of electrolyte in the inter-electrode space were observed using an optical microscope.

\section{EXPERIMENTAL RESULTS AND DISCUSSION}

Magnetic field influences both the deposition rate and the morphology of the electrodeposits (see Figs. 1, 2, respectively). The major impact of the magnetic field on the polarization curves is as follows. (i) The fieldinduced enhancement of the limiting current density $j_{l}$ varies with field as $B^{1.4}$, in agreement with other experimental results [17]. (ii) The time $\tau_{p}$, at which a voltage drops in the cathode and the probes' potentials occur, increases monotonically with increase of $B$ (Fig. 1). This has its origin in the MHD stimulated convection that retards the passivation of the electrodes. (iii) The sign of the potential difference between the lower and the upper probes changes at the magnetic field $B_{t r}$ (in our case $B_{t r} \cong 0.3 \mathrm{~T}$ ). This one evidences that the thickness of the diffusion layer changes when moving along the cathode surface from its top to the bottom even at zero applied field, and at the field $B_{t r}$, the concentration gradient in the electrolyte along the cathode changes its sign. This is also confirmed by the observed fact that the gradient of the density of nucleation centres on the cathode surface varies synchronously with the

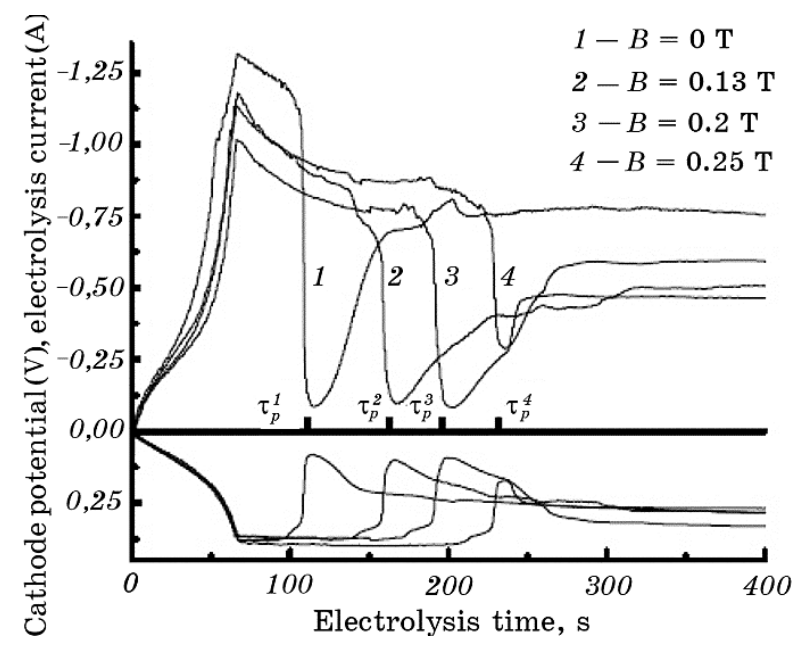

Fig. 1. The dependences of cathode potential (upper curves) and electrolysis current (lower curves) on the electrolysis time for different magnetic fields. 
potential difference between the probes. This gradient is the origin of the additional diffusion over the cathode plane [17], and this diffusive flow is affected by Lorentz force oriented parallel to the initial current lines. Being rotated by $180^{\circ}$, magnetic field turns the moving ions either opposite or in the direction of flow, resulting in the different current increase for both field orientations [17].

More drastically, magnetic field influences the structure of the electrodeposit. In zero applied field, one has the typical fractal structure
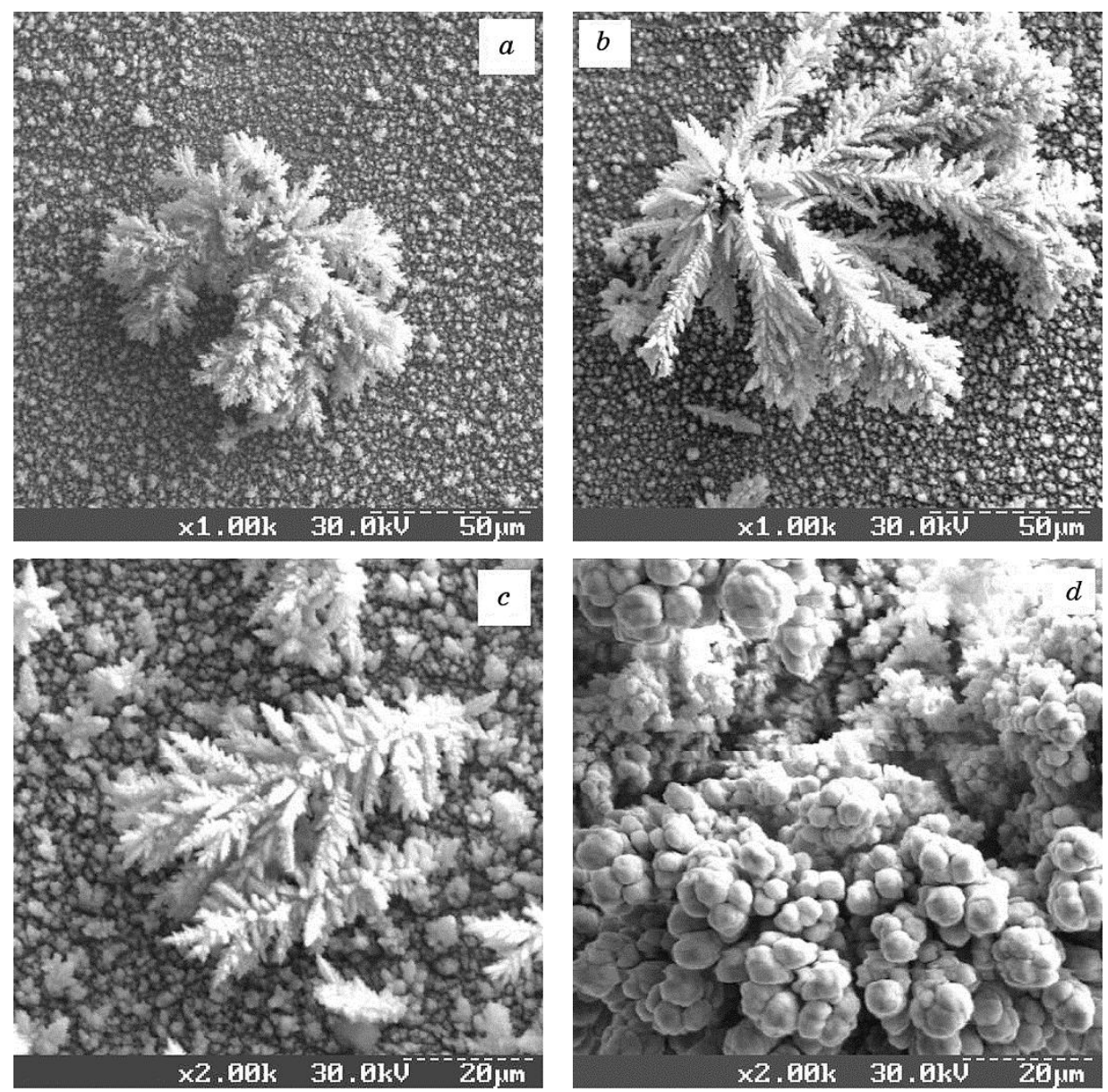

Fig. 2. The morphology of electrodeposits obtained in different magnetic fields: $B=0 \mathrm{~T}(a) ; B=0.13 \mathrm{~T}(b)$, magnetic field is oriented perpendicular to the electrical current lines in the cuvette; $B=0.13 \mathrm{~T}(c)$, magnetic field oriented parallel to the electrical current lines; $B=0.31 \mathrm{~T}(d)$, magnetic field oriented perpendicular to the electrical current lines. Duration of electrolysis is $22 \mathrm{~s}$ for all pictures. 
of the deposited aggregates, whose shape is of spherical symmetry and has no preferred directions of growth (Fig. 1,a). Magnetic field oriented either parallel or perpendicular to the electric current lines establishes the preferred directions of growth and changes the morphology of the electrodeposits (Fig. 2, $b, c$ ). Directions of growth are primary defined by the convective flows, and in our experiments, they remain the same for each of the both orientations of magnetic field. A further increase of field strength (for fields $B>0.3 \mathrm{~T}$ ) removes the preferred growth directions and essentially changes structure and shape of the deposits (Fig. 2, d). In contrast to the flat electrochemical cell [7, 8], no magnetic-field-induced chirality was observed.

It is well established that the deposit structure (for a given electrolyte composition, cuvette shape, zero magnetic field) is primary defined by the electrolysis regime, e.g., one has a smooth surface of the deposit (films) for the electrochemical kinetics, and structures of various shape and morphology for the regime of the diffusion kinetics [1]. In what follows, we confine ourselves to the case of the diffusion kinetics, for which all the results presented here were obtained.

Objects of the primary interest considered in the present work are ramified (fractal-like) deposits made of nanosize elements obtained in regime of the diffusion-limited kinetics. As seen from Fig. 2, $a-d$, imposition of the magnetic field changes all the shape, morphology and structure of the electrodeposits (see also [7-10]). Qualitatively, impact of the magnetic field can be introduced through the field-dependent thickness of the diffusion layer $\delta$, which defines the regime of an electrolytic process $[1,9,10]$ :

$$
j_{l}=\frac{n F D c_{0}}{\delta},
$$

where $F$ is the molar charge $(96485 \mathrm{C} /$ mole), $n$ is the cation charge $(1,2), c_{0}$ is the ionic concentration in the bulk of the solution, and $D$ is the diffusion coefficient. The field dependence $\delta(B)$ is the result of the magnetohydrodynamic (Lorentz) force acting on the ions in electrolyte that results in the additional stirring of the electrolyte and to corresponding decrease of $\delta$ [8-10].

A more comprehensive picture of the MHD effects on the magnetoelectrolysis has to incorporate into the equations governing the process other forces acting in an electrochemical cell, i.e., the driving forces due to the concentration and field gradients, paramagnetic force, MHD drag force due to non-zero conductivity of the moving electrolyte, viscous force, etc. (as it is already mentioned, despite being different by orders of magnitude, all the forces have a measurable effect), as well as chemical reactions on the electrode [8-10, 18, 19]. In our case, it will be a set of coupled Navier-Stokes and convective diffusion equations $[8,18]$ bounded by the geometry of the cell and the elec- 
trodes' shape. Finding a numerical solution to such the system for arbitrary values of parameters poses a rather formidable task; as an exception, for some geometries and limited number of acting forces, an analytical solution can be obtained $[20,21]$.

The general fractal-like picture of the deposited aggregates observed in our experiment can be quantitatively described by the diffusion limited aggregation (DLA) model [15, 22, 23], which supposes that the deposited clusters grow by joining separate particles. In the case of electrolysis, it is the $\mathrm{Cu}$ atoms, delivered through the electrolyte as $\mathrm{Cu}^{2+}$ cations and reduced to $\mathrm{Cu}$ at the cathode. Having found the mass transfer dependence as the solution to the afore-mentioned set of equations, one can directly apply it to the model of fractal growth using the clear correspondence between (i) the trajectories of ions (velocity field in the MHD equations) near the growing electrodeposit and offlattice random walks in the DLA model [23], and (ii) the ions energy in the cathode-electrolyte interface area related to the cathode potential by the Lippman equation [19] and the sticking probabilities in the DLA model. In that way, one can give a physical meaning to purely mathematical parameters of the DLA model.

The more detailed study of MHD effects governing the fractal electrodeposition as well as finding solution to corresponding equations for some selected conditions, and detailed comparison of theoretical and experimental data will be presented in our further works.

\section{CONCLUSIONS}

Magnetic electrodeposition is an attractive interdisciplinary area with good opportunities for fabrication of novel materials and nanostructures. We have shown that relatively low magnetic fields significantly change the morphology of the copper electrodeposits allowing us to fabricate various sophisticated nanosize structures. Although the empirical rules defining the deposit structure are basically known, there is not so far any cogent and self-consistent theoretical model capable to predict the morphology of the growing deposits from the first principles. In the present work, we have outlined the foundations of such a model and shown its interconnection with the diffusion-limited aggregation model used to describe the fractal growth of the electrodeposits.

\section{REFERENCES}

1. A. I. Levin, Elektrokhimiya Tsvetnykh Metallov (Moscow: Metallurgiya: 1982) (in Russian).

2. R. Winand, Electrochim. Acta, 43: 2925 (1998).

3. S. Trasatti, Electrochim. Acta, 36: 1659 (1991).

4. C. Wang and S. Chen, J.Serb.Chem.Soc., 66: 477 (2001). 
5. G. Hinds, J. M. D. Coey, and M. E. G. Lyons, J. Appl. Phys., 83: 6447 (1998).

6. E. Z. Gak, E. H. Rokhinson, and N. F. Bondarenko, Elektrokhimiya, 9: 528 (1975) (in Russian).

7. I. Mogi and M. Kamiko, J. Crystal Growth, 166: 276 (1996).

8. T. Z. Fahidy, Prog. Surf. Sci., 68: 155 (2001).

9. J. M. D. Coey, Europhysics News, 34, No. 6: 15 (2003).

10. J. M. D. Coey, G. Hinds, C. O’Reily et al., Mater. Sci. Forum, 373-376: 1 (2001).

11. R. N. O'Brien and K. S. V. Santhanam, Electrochim. Acta, 32: 1679 (1987).

12. S. Hill, Materials World, 6: 221 (1998).

13. R. P. Devaty and A. J. Sievers, Phys. Rev. Lett., 52: 1344 (1984).

14. G. A. Niklasson and C. G. Granqvist, Phys. Rev. Lett., 56: 256 (1986).

15. B. M. Smirnov, Fizika Fraktalnykh Klasterov (Moscow: Nauka: 1991) (in Russian).

16. F. Romm, Microporous Media: Synthesis, Properties and Modeling (New York: Marcel Dekkel Ltd.: 2004).

17. A. Bund, S. Koehler, H. H. Kuehlein, and W. Plieth, Electrochim. Acta, 49: 147 (2003).

18. V. G. Levich, Fiziko-Khimicheskaya Gidrodinamika (Moscow: GIFML: 1959) (in Russian).

19. V. V.Skorchelleti, Teoreticheskaya Elektrokhimiya (Leningrad: Khimiya: 1974) (in Russian).

20. T. Z. Fahidy, J.Appl. Electrochem., 32: 551 (2002).

21. B. K. Jha, Heat and Mass Transfer., 37: 329 (2001).

22. T. A. Witten and L. M. Sander, Phys. Rev. Lett., 47: 1400 (1981).

23. J. C. Mansur Filho, A. G. Silva, A. T. G. Carvalho, and M. L. Martins, Physica A, 350: 393 (2005). 